\title{
RESCUE ME!: THE ATTACK ON SETTLEMENT NEgotiations AFTER RESQNET V. LANSA
}

\author{
Parker Kubl $l^{\dagger}$
}

Patent litigation often results in settlement with the parties agreeing to a license involving the patent-in-suit. ${ }^{1}$ Licenses arising out of litigation are commonly referred to as settlement licenses or litigation licenses. The terms of a license resulting from settlement negotiations may depend on many factors such as the technology involved, the competitive position of the parties, the anticipated cost of further litigation, and the relative strengths of each party's claims. ${ }^{2}$ Prior licenses involving the patent-in-suit play a central role in establishing damages for patent infringement. Although parties emphasize prior licenses, courts have traditionally deemed settlement licenses inadmissible as evidence due to the concern that these licenses lack adequate probative value. Courts have found that two considerations weigh against admission: the complexities of litigation and the multitude of factors unrelated to the value or validity of a patent that nonetheless affect the parties' decision to settle. ${ }^{3}$ Despite the traditional bias against admitting settlement licenses, the Federal Circuit's opinion in ResQNet.com Inc. v. Lansa Inc. ${ }^{4}$ brought the issue of admissibility of settlement licenses back into question.

In ResQNet, the Federal Circuit vacated and remanded a damage award for patent infringement because the district court improperly determined the reasonable royalty rate. ${ }^{5}$ After evaluating the various licenses considered by the district court, the Federal Circuit stated that "the most reliable license in

(C) 2011 Parker Kuhl.

† J.D. Candidate, 2012, University of California, Berkeley School of Law.

1. Peter S. Menell et al., Patent Case Management Judicial Guide $\$ \$ 1.2$, 2.6.8 (2009).

2. Fenner Invs, Ltd. v. Hewlett-Packard Co., No. 6:08-CV-273, 2010 WL 1727916, at *3 (E.D. Tex. Apr. 28, 2010) (listing possible reasons parties enter into settlements, including "cost of additional litigation," "relative financial positions of the parties," the "risk of a sizeable verdict against a defendant," and the risk of "a finding of invalidity or unenforceability against a plaintiff").

3. See infra Section I.C.

4. See generally ResQNet.com, Inc. v. Lansa, Inc., 594 F.3d 860 (Fed. Cir. 2010).

5. Id. at 868 . 
this record arose out of litigation." Based on this statement, some district courts have expanded admissibility of settlement licenses in patent cases and have also opened up discovery of the underlying settlement negotiations, leaving litigators and other courts questioning how licenses arising out of settlement negotiations may be used in future litigation. ${ }^{8}$ Of particular interest is the inconsistent treatment of settlement licenses within the Eastern District of Texas.' This uncertainty is causing parties to fear that negotiations in one case will be used against them down the road, which could have a significant chilling effect on settlement generally.

This Note attempts to address several issues arising from the Res QNet decision. Part I reviews the discovery and admissibility of litigation-induced licenses as well as their underlying negotiations. Part II discusses the ResQNet case and how district courts have interpreted the opinion. Part III addresses three key questions arising from ResQNet. (1) to what extent settlement licenses and negotiations should be admissible or discoverable in the wake of the ResQNet decision; (2) if admitted, how settlement licenses should factor into a reasonable royalty analysis; and (3) how increased admissibility might affect patent litigation and settlement negotiations. This Note argues that courts should decide the admissibility of settlement licenses on a case-by-case basis so that judges can balance the relevant rules of evidence and civil procedure in making these determinations. It also argues that increased discovery of settlement negotiations based on ResQNet conflicts with the recent judicial policy trend to promote settlement, and that the justification being used to support discovery relies on a flawed assumption regarding the reliability of settlement communications.

\section{BACKGROUND ON SETTLEMENT LICENSES AND NEGOTIATIONS}

\section{A. USE OF LICENSING AGREEMENTS IN REASONABLE ROYALTY CaLCULATIONS}

In patent infringement cases, federal statute provides for "damages adequate to compensate for the infringement, but in no event less than a reasonable royalty for the use made of the invention by the infringer." ${ }^{10}$ In
6. Id. at 872 .
7. See infra Section II.C.
8. See infra Section II.C.
9. See infra Section II.C.1.
10. 35 U.S.C. $\$ 284(2006)$. 
the absence of an established royalty rate, courts base damages on a reasonable royalty, which is "that amount which would have been set in a hypothetical negotiation between a willing patent owner and a willing potential user as of the date when the infringement began in fact and on the assumption that the patent was valid and entitled to respect." Pacific Corp. v. United States Plywood Corp., the Southern District of New York identified fifteen factors for courts to consider when determining a reasonable royalty. ${ }^{12}$ Under the first factor, courts should look to "royalties

11. 7 DONALD S. CHISUM, CHISUM ON PATENTS $\$ 20.03(2010)$.

12. Georgia-Pacific Corp. v. U.S. Plywood Corp., 318 F. Supp. 1116, 1120 (S.D.N.Y. 1970). The factors are:

1. The royalties received by the patentee for the licensing of the patent in suit, proving or tending to prove an established royalty.

2. The rates paid by the licensee for the use of other patents comparable to the patent in suit.

3. The nature and scope of the license, as exclusive or non-exclusive; or as restricted or non-restricted in terms of territory or with respect to whom the manufactured product may be sold.

4. The licensor's established policy and marketing program to maintain his patent monopoly by not licensing others to use the invention or by granting licenses under special conditions designed to preserve that monopoly.

5. The commercial relationship between the licensor and licensee, such as, whether they are competitors in the same territory in the same line of business; or whether they are inventor and promot $[\mathrm{e}] \mathrm{r}$.

6. The effect of selling the patented specialty in promoting sales of other products of the licensee; the existing value of the invention to the licensor as a generator of sales of his non-patented items; and the extent of such derivative or convoyed sales.

7. The duration of the patent and the term of the license.

8. The established profitability of the product made under the patent; its commercial success; and its current popularity.

9. The utility and advantages of the patent property over the old modes or devices, if any, that had been used for working out similar results.

10. The nature of the patented invention; the character of the commercial embodiment of it as owned and produced by the licensor; and the benefits to those who have used the invention.

11. The extent to which the infringer has made use of the invention; and any evidence probative of the value of that use.

12. The portion of the profit or of the selling price that may be customary in the particular business or in comparable businesses to allow for the use of the invention or analogous inventions.

13. The portion of the realizable profit that should be credited to the invention as distinguished from non-patented elements, the manufacturing process, business risks, or significant features or improvements added by the infringer.

14. The opinion testimony of qualified experts. 
received by the patentee for the licensing of the patent-in-suit, proving or tending to prove an established royalty." ${ }^{33}$ Among these factors, the factor that looks to prior and existing licenses involving the patent-in-suit is often the most influential. ${ }^{14}$ Despite the emphasis placed on direct licenses for the disputed technology, courts have traditionally held licenses arising out of litigation inadmissible because they are not probative of a hypothetical negotiation between the two parties at the time the infringement began, even if the licenses involve the patent-in-suit. ${ }^{15}$ The Supreme Court took this position over a century ago in Rude v. Westcott, stating:

It is clear that a payment of any sum in settlement of a claim for an alleged infringement cannot be taken as a standard to measure the value of the improvements patented, in determining the damages sustained by the owners of the patent in other cases of infringement. Many considerations other than the value of the improvements patented may induce the payment in such cases. The avoidance of the risk and expense of litigation will always be a potential motive for a settlement. ${ }^{16}$

The statement in ResQNet that the most reliable license in the record arose out of litigation is at odds with the traditional bias against using settlement licenses to determine patent damages. Part III, infra, explores the implications of the potential use of settlement license in royalty analysis in the wake of ResQNet.

15. The amount that a licensor (such as the patentee) and a licensee (such as the infringer) would have agreed upon (at the time the infringement began) if both had been reasonably and voluntarily. trying to reach an agreement; that is, the amount which a prudent licensee-who desired, as a business proposition, to obtain a license to manufacture and sell a particular article embodying the patented invention-would have been willing to pay as a royalty and yet be able to make a reasonable profit and which amount would have been

Id. acceptable by a prudent patentee who was willing to grant a license.

13. Georgia-Pacific, 318 F. Supp. at 1120.

14. 7 CHISUM, supra note $11, \S 20.03$.

15. Rude v. Westcott, 130 U.S. 152, 164 (1889); see also Wang Labs., Inc. v. Mitsubishi Elecs. Am., Inc., 860 F. Supp. 1448, 1452 (C.D. Cal. 1993) ("It is a century-old rule that royalties paid to avoid litigation are not a reliable indicator of the value of a patent, and should therefore be disregarded when determining reasonable royalty rates.").

16. Rude, 130 U.S. at 164. 


\section{B. USE OF LICENSES TO SUPPORT VALIDITY}

Prior licenses can also provide evidence of nonobviousness to support a claim of validity. ${ }^{17}$ In Grabam v. John Deere, the Supreme Court held that in determining the nonobviousness of an invention under 35 U.S.C. $₫ 103$, courts should consider (1) "the scope and content of the prior art," (2) "differences between the prior art and the claims at issue," and (3) "the level of ordinary skill in the pertinent art." ${ }^{, 18}$ Additionally, the Court stated that commercial success was a "secondary consideration" that "might be utilized to give light to the circumstances surrounding the origin of the subject matter sought to be patented." 19 Some courts consider licensing by market competitors to be an indication of commercial success supporting validity based on the theory that competitors would not willingly agree to pay for the technology if they did not believe the patent was valid. ${ }^{20}$

Although commercial success is recognized as a secondary consideration, its relevance is disputed by courts. ${ }^{21}$ Also, the same litigation issues that cause concern about the value of settlement licenses in determining damages also apply when using these licenses to show the nonobviousness of a patent. Thus, prior licenses that have been influenced by litigation may be even less relevant to proving nonobviousness via commercial success than other licenses. If the decision in ResQNet results in increased admission of settlement licenses, courts should be aware of the questionable value of these licenses for determining nonobviousness in addition to damages. ${ }^{22}$ Section III.A, infra, further discusses how the potential use of settlement licenses to show commercial success should affect their admissibility.

\section{ADMISSIBILITY AND DISCOVERY OF SETTLEMENT LICENSES AND NEGOTIATIONS}

Exclusion of settlement licenses for purposes of establishing a reasonable royalty or assessing nonobviousness is typically based on Federal Rules of Evidence 403 and 408. The Federal Rule of Civil Procedure 26 governs discovery of both the licenses and the underlying settlement negotiations. This Section provides background information on these rules.

17. 2 CHISUM, supra note $11, \S 5.05$.

18. Graham v. John Deere, 383 U.S. 1, 17 (1966).

19. Id. at $17-18,35-36$.

20. 2 CHISUM, supra note $11, \$ 5.05$.

21. Id.

22. The probative value of settlement licenses for showing nonobviousness is also addressed infra Section III.B. 


\section{Federal Rule of Evidence 403}

Federal Rule of Evidence 403 provides for the exclusion of evidence on the grounds of prejudice, confusion, or waste of time, even if the evidence is otherwise relevant. ${ }^{23}$ It states that "[a]lthough relevant, evidence may be excluded if its probative value is substantially outweighed by the danger of unfair prejudice, confusion of the issues, or misleading the jury, or by considerations of undue delay, waste of time, or needless presentation of cumulative evidence." ${ }^{24}$ Rule 403 allows courts to account for factors besides relevance when deciding whether a piece of evidence should be admissible. ${ }^{25}$ According to the Advisory Committee Notes on Rule 403, "[s]ituations in this area call for balancing the probative value of and need for the evidence against the harm likely to result from its admission."26 The "unfair prejudice" aspect of Rule 403 only applies to jury trials, because trying a case in front of a judge does not carry the same risk of prejudice necessitating the exclusion of evidence. ${ }^{27}$ Thus, probative evidence should only be excluded under Rule 403 in a bench trial if the evidence would be cumulative or a waste of time.

There are some alternatives to excluding evidence altogether under Rule 403. Providing the jury with limiting instructions may be appropriate as long as the prejudice and confusion remaining after the instructions do not substantially outweigh the probative value of the evidence. ${ }^{28}$ The availability of other means of proof may also be an appropriate factor for a court to consider. ${ }^{29} \mathrm{~A}$ court may exclude evidence when there are less prejudicial alternative means to prove the fact at issue or may admit potentially confusing evidence when no better evidence exists. ${ }^{30}$

A common argument for excluding litigation licenses is that they lack probative value. ${ }^{31}$ The possibility that admitting licenses will confuse or

23. FED. R. EVID. 403.

24. Id.

25. FED. R. EVID. 403 advisory committee's note ("The case law recognizes that certain circumstances call for the exclusion of evidence which is of unquestioned relevance.").

26. Id.

27. 2 Michael M. Martin, Federal Rules of Evidence Manual, $₫ 403.02$ (citing Schultz v. Butcher, 24 F.3d 626, 632 (4th Cir. 1994) (holding that evidence in a bench trial should not be excluded on the ground of unfair prejudice)).

28. FED. R. EVID. 105 (addressing limiting instructions).

29. FED. R. Evid. 403 advisory committee's note ("The availability of other means of proof may also be an appropriate factor.").

30. FED. R. EVID. 408 advisory committee's note.

31. See Rude v. Westcott, 130 U.S. 152, 164 (1889); Wang Labs., Inc. v. Mitsubishi Elecs. Am., Inc., 860 F. Supp. 1448, 1452 (C.D. Cal. 1993). 
unfairly prejudice the jury is also a common concern. ${ }^{32}$ A party may weigh various factors when considering whether to negotiate a settlement or take a case to trial, and the true value of the patent-in-suit is only one of those considerations. ${ }^{33}$ These circumstances add complexity for a jury attempting to accurately evaluate how much premium or discount should be assigned to a license that arose under these conditions. Evidence of a previous settlement on the patent-in-suit could create presumptions in the jury's mind. The jury might assume that a patent is invalid if the plaintiff settled. Conversely, a jury might assume that a defendant would never settle an invalid patent, creating a presumption of validity.

\section{Federal Rule of Evidence 408}

Some courts may also rely on Federal Rule of Evidence 408 to exclude settlement licenses. ${ }^{34}$ Rule 408 excludes evidence of compromise and offers to compromise for proving the validity or amount of a claim. ${ }^{35}$ It provides that the following evidence is "not admissible on behalf of any party, when offered to prove liability for, invalidity of, or amount of a claim that was disputed as to validity or amount": "(1) furnishing or offering or promising to furnish or accepting or offering or promising to accept a valuable consideration in compromising or attempting to compromise the claim; and (2) conduct or statements made in compromise negotiations regarding the claim." 36 The rule applies even when evidence of compromise is proffered by the party that made the settlement offer. ${ }^{37}$

32. See, e.g., Fenner Invs., Ltd. v. Hewlett-Packard Co., No. 6:08-CV-273, 2010 WL 1727916 , at *2 (E.D. Tex. April 28, 2010) (" $[$ P]arties are prejudiced by being forced to litigate the similarities and differences in the facts regarding the 'same' claims against other defendants to determine what, if any, light the [settlement agreement] sheds on the value of the claim against [this defendant]."); Pioneer Corp. v. Samsung SDI Corp., No. 2:06-cv-384, slip op. at 9 (E.D. Tex. Oct. 2, 2008) (" $[E]$ ven if negotiations, offers, and agreements reached under the threat of litigation had some probative value, such value would be too slight and clearly outweighed by the danger of unfair prejudice and confusion.'); Spreadsheet Automation Corp. v. Microsoft Corp., 587 F. Supp. 2d 794, 801 (E.D. Tex. 2007) ("[S]ettlements[] and licenses made under the threat of litigation ... would likely confuse the jury ... [and are] inadmissible under Federal Rule of Evidence 403.").

33. Rude, 130 U.S. at 164; Fenner, 2010 WL 1727916, at *2-3. 1983).

34. See, e.g., Hanson v. Alpine Valley Ski Area, Inc., 718 F.2d 1075, 1078-79 (Fed. Cir.

35. FED. R. EVID. 408.

36. Id.

37. See, e.g., Pierce v. F.R. Tripler \& Co., 955 F.2d 820, 828 (2d Cir. 1992) (applying Rule 408 regardless of which party attempts to offer the evidence). 
Rule 408 attempts to encourage settlement by excluding from trial most offers to settle and statements made during settlement negotiations when they are offered to show the validity or amount of a claim. ${ }^{38}$ In theory, preventing use of compromise negotiations at trial promotes more open and honest communication, which in turn increases the chance of settling a case. The rationale for promoting settlement is that it is more efficient and reduces the demands on the court system. ${ }^{39} \mathrm{~A}$ secondary rationale is that compromise evidence has little or no probative value when used to prove the validity or amount of a claim because an offer to settle may be an attempt at peace rather than an admission of liability or evidence of weakness. ${ }^{40}$

Rule 408 clearly applies to existing claims in an ongoing case, but courts differ in how they have applied the rule to negotiations during other litigations or with third parties. Some courts do not apply Rule 408 to settlement agreements from prior litigations or that involve a third party. ${ }^{41}$ Others do not make this distinction. ${ }^{42}$ Courts that apply Rule 408 broadly to prior litigation and third party agreements claim that doing so provides a stronger incentive for compromise. ${ }^{43} \mathrm{~A}$ narrower rule of exclusion may deter litigants from open negotiations in instances where multiple suits have been or might be brought. ${ }^{44}$ Similarly, when the parties to a suit have previously engaged in related settlement negotiations, the compromise evidence should be excluded based on the same rationale.

38. FED. R. EVID. 408 advisory committee's note.

39. FED. R. EVID. 408 advisory committee's note.

40. Id.

41. Sunstar, Inc. v. Alberto-Culver Co., No. 01 C 0736, 2004 WL 1899927, at $* 29$ (N.D. Ill. Aug. 23, 2004) ("Substantial authority supports [the plaintiff's] contention that Rule 408 only bars evidence of settlement negotiations to prove the validity or amount of the claim under negotiation."); Donnelly Corp. v. Gentex Corp., 918 F. Supp. 1126, 1133-34 (W.D. Mich. 1996) ("[]t is obvious that [Rule 408] itself does not preclude evidence of these compromises because the offers to compromise the claims do not concern the claim being litigated in this case.").

42. See, e.g., Hudspeth v. C.I.R., 914 F.2d 1207, 1213 (9th Cir. 1990) (stating that the "contention that Rule $\mathbf{4 0 8}$ does not apply when third party compromises are involved is not tenable" and holding that "Rule 408 does apply to situations where the party seeking to introduce evidence of a compromise was not involved in the original compromise.").

43. Cf. FED. R. EVID. 408 advisory committee's note (" $[\mathrm{A}]$ more consistently impressive ground is promotion of the public policy favoring the compromise and settlement of disputes.").

44. See, e.g., Branch v. Fidelity \& Cas. Co., 783 F.2d 1289, 1294 (5th Cir. 1986) ("The spectre of a subsequent use to prejudice a separate and discrete claim is a disincentive which Rule 408 seeks to prevent."); United States v. Contra Costa County Water Dist., 678 F.2d 90, 92 (9th Cir. 1982) (holding a settlement with another party previously dismissed from the case inadmissible under Rule 408). 
In parties' attempts to exclude litigation licenses, Rule 408 often receives less attention than Rule 403. One possible reason is that Rule 408 only applies if the evidence is offered to prove the validity or amount of the claim. Offers to compromise are often admitted under another context. There are several reasons why a settlement agreement may find its way into a case without being subject to Rule 408 . One example, already discussed, is that some jurisdictions do not apply Rule 408 to third-party agreements. ${ }^{45}$ Second, the parties simply may not have presented a proper objection. This could occur for any number of reasons. During litigation, parties are forced to pick their battles and may feel that making a Rule 403 argument is stronger than arguing Rule 408. Another possibility is that the parties agree to admit the license, potentially with stipulations. This could result in a redacted version or accompanying limiting instructions. ${ }^{46}$ Parties may also agree to admission of the license provided that settlement communications would still be privileged. Finally, the proponent may have been able to get the license admitted for a purpose other than to prove validity or amount, such as to prove willingness to license.

\section{Federal Rule of Civil Procedure 26}

Federal Rule of Civil Procedure 26(b)(1) states that "parties may obtain discovery regarding any nonprivileged matter that is relevant to any party's claim or defense" or "appears reasonably calculated to lead to the discovery of admissible evidence." Although settlement licenses are usually inadmissible under the rules of evidence, they are generally discoverable based on the potential for the agreements to lead to other admissible evidence. $^{47}$

45. See supra Section I.C.2.

46. See, e.g., Datatreasury Corp. v. Wells Fargo \& Co., No. 2:06-CV-72 DF, 2010 WL 903259, at *2 (E.D. Tex. Mar. 4, 2010) discussed infra Section II.C.1.

47. See, e.g., 4 Robert A. MatTHews, JR., ANNOTAted Patent Digest, $₫ 30: 101$ (2010) (citing West v. Jewelry Innovations, Inc., 2009 WL 668695, at *1-2 (N.D. Cal. Mar. 13,2009 ) (granting motion to compel discovery of settlement agreements); Bd. of Trs. of Leland Stanford Junior Univ. v. Tyco Int'l Ltd., 253 F.R.D. 521, 522-23 (C.D. Cal. 2008) (granting motion to compel production of a settlement agreement and finding no federal settlement privilege); Phoenix Solutions Inc. v. Wells Fargo Bank, N.A., 254 F.R.D. 568, 583 (N.D. Cal. 2008) (allowing discovery of settlement negotiations even though settlement had not been completed); Rates Tech., Inc. v. Cablevision Sys. Corp., 2006 WL 1026044, at *1-2 (E.D.N.Y. Apr. 14, 2006) (ordering production of "all documents concerning any licenses, settlement agreements, covenants not to sue, or any other agreements concerning either or both of the patents at issue" even if the material would be inadmissible under FRE 408)). 
Treatment of settlement negotiations is more varied compared to decisions on the admissibility of settlement licenses. Similar to the rationale for excluding offers to compromise from evidence under Federal Rule of Evidence 408, denying discovery of settlement negotiations encourages open and honest communication for the purpose of promoting settlement. Since Rule 408 is an evidentiary rule, however, it only prevents admission and not discovery of settlement-related documents. As a result, some courts have found settlement negotiations discoverable under Rule 26(b)(1) based on the potential to lead to other admissible evidence. ${ }^{48}$ But even courts that find final agreements to be discoverable are typically reluctant to allow discovery of the settlement negotiations in fear of disturbing open and free communication during negotiations. Generally, "courts have been reluctant to order the production of documents relating to ongoing settlement negotiations, absent a showing of substantial need or, at a minimum, a particularized showing of the relevance of such documents." ${ }^{399}$ For example, prior to ResQNet, the Eastern District of Texas (following the Sixth Circuit's decision in Goodyear Tire \& Rubber Co. v. Chiles Power Supply, Inc. ${ }^{50}$ " adopted a bright-line rule that settlement negotiations are privileged while the resulting license agreement is discoverable."

\section{RESQNET.COM INC. V. LANSA INC.}

\section{A. FACTS AND PROCEDURAL History}

ResQNet.com ("ResQNet") initially sued Lansa for infringement of five patents, alleging that Lansa's "NewLook" product infringed one or more claims of the asserted patents. ${ }^{52}$ The patented technology related to methods

48. 4 MATTHEWS, supra note 47, \$ 30:101 (citing Tyro Int'l, 253 F.R.D. at 523 (finding no federal privilege preventing the discoverability of settlement agreements); Pboenix Solutions, 254 F.R.D. at 583 (granting motion to compel discovery of settlement negotiations and rejecting the contention that the negotiations were privileged)); see also In re Subpoena Issued to Commodity Futures Trading Comm's, 370 F. Supp. 2d 201, 211 (D.D.C. 2005) (declining to recognize the settlement privilege in Goodyear Tire \& Rubber Co. v. Chiles Power Supply, Inc., 332 F.3d 976 (6th Cir. 2003)).

49. 4 MatTHEws, supra note 47, $\$ 30: 101$ (citing Primestar 24 Joint Venture v. Echostar Commc'ns Corp., No. 98civ6738, 2000 WL 97680, at *4 (S.D.N.Y. Jan. 28, 2000); United States v. Am. Soc'y of Composers, Authors, \& Publishers, No. CIV 13-95, 1996 WL 157523, at *2 (S.D.N.Y. Apr. 3, 1996)).

50. Goodyear, 332 F.3d 976.

51. Tyco Healthcare Group LP, v. E-Z-Em, Inc., No. 2:07-CV-262 (TJW), 2010 WL 774878, at *2 (E.D. Tex. Mar. 2, 2010).

52. ResQNet.com, Inc. v. Lansa, Inc., 594 F.3d 860, 863-64 (Fed. Cir. 2010). 
for downloading screen display information from a remote mainframe computer for display on a local personal computer. ${ }^{53}$

The Southern District of New York conducted a bench trial and rendered a decision in $2008 .{ }^{54}$ At the time of trial, the claims at issue were claim one of U.S. Patent No. 5,831,608 (the '608 patent) and claim one of U.S. Patent No. 6,295,075 (the '075 patent). ${ }^{55}$ The district court ruled that the ' 075 patent was valid and infringed by Lansa, and that the ' 608 patent was not infringed. ${ }^{56}$ The parties agreed that the appropriate method of calculating damages was to determine a reasonable royalty, since lost profits could not be proven. ${ }^{57}$

At trial, ResQNet offered expert testimony and an expert report to support its damages claim. ${ }^{58}$ The expert addressed each of the Georgia-Pacific factors and concluded that an appropriate reasonable royalty rate for use of the patents-in-suit was 12.5 percent." The court found that " $[t]$ he key factor driving [the expert's] ultimate conclusion was the first [factor], the royalties ResQNet received for actual licenses of the patents-in-suit. ${ }^{300}$ The district court acknowledged that the rate in one of the prior licenses "was reached by virtue of settlement with [another company] and without the assumption ... that the ' 075 patent was valid and enforceable." ${ }^{\text {161 }}$ ResQNet's expert claimed to account for the fact that the license arose out of settlement and that it had a royalty rate lower than 12.5 percent. ${ }^{62}$ Lansa did not offer expert testimony on the issue of damages. ${ }^{63}$

Ultimately, the district court awarded damages of $\$ 506,305$ for past infringement based on a hypothetical royalty of 12.5 percent, plus prejudgment interest. $^{64}$ ResQNet's motion for a permanent injunction was denied, and instead, the district court imposed a license for future activity

53. Id.

54. ResQNet.com, Inc. v. Lansa, Inc. (ResQNet S.D.N.Y.), 533 F. Supp. 2d 397 (S.D.N.Y. 2008).

55. ResQNet, 594 F.3d at 863.

56. $I d$.

57. ResQNet S.D.N.Y., 533 F. Supp. $2 \mathrm{~d}$ at 415.

58. Id. at 417.

59. Id.

60. Id.

61. Id. The royalty rate agreed to in the settlement was under a protection order.

62. Id. at 418 (" $[\mathrm{O}]$ nly two straight patent licenses, one of which was lower than $12.5 \%$, were granted in the shadow of litigation, and without the assured validity of the ' 075 Patent.").

63. Id. at 417.

64. ResQNet.com, Inc. v. Lansa, Inc., 594 F.3d 860, 863 (Fed. Cir. 2010). 
covered by the ' 075 patent with a royalty rate of 12.5 percent. ${ }^{65}$ ResQNet appealed the district court's rulings on validity and infringement and Lansa cross-appealed the damages award.

\section{B. The FedERAL CIRCUIT'S ANALYsis}

On appeal, the Federal Circuit affirmed the district court's rulings on the issues of validity and infringement for both the ' 608 and ' 075 patents. ${ }^{66}$ The court vacated the damages award and remanded the case for redetermination of damages. ${ }^{67}$ The court held that "the district court's award relied on speculative and unreliable evidence divorced from proof of economic harm linked to the claimed invention and was inconsistent with sound damages jurisprudence." $" 68$

The Federal Circuit decision relied heavily on its opinion in Lucent Technologies, Inc. v. Gateway. ${ }^{69}$ In Lucent, the Federal Circuit rejected a patentee's reliance on licenses in determining a reasonable royalty because "some of the licence [sic] agreements [were] radically different from the hypothetical agreement under consideration." ${ }^{70}$ Under Lucent, the district court must link licenses to the infringed patent so the fact finder can "adequately evaluate[] the probative value of [the] agreements.",71

The court held that the majority of the licenses on which ResQNet relied had the same problem as the Lucent licenses, meaning there was a lack of reliable evidence linking the licenses to the claimed invention. ${ }^{72}$ The expert based his damages opinion on seven ResQNet licenses, five of which had no relation to the claimed invention, according to the Federal Circuit. ${ }^{73}$ These five licenses (which the court called "re-bundling licenses") provided finished software products and source code, as well as services such as training, maintenance, marketing, and upgrades, to other software companies in exchange for ongoing revenue-based royalties. ${ }^{74}$ Two of these licenses had a top rate of 25 percent, two others had a top rate of 30 percent, and one had a top rate of 40 percent. $^{75}$ According to the court, none of these licenses

65. Id.

66. Id.

67. Id.

68. Id. at 868 .

69. Lucent Techs., Inc. v. Gateway, 580 F.3d 1301, 1327-28 (Fed. Cir. 2009).

70. ResQNet, 594 F.3d at 869 (citing Lucent).

71. Lucent, 580 F.3d at 1328.

72. ResQNet, 594 F.3d at 869.

73. Id. at $870-71$.

74. Id. at 870 .

75. Id. 
mentioned the patents in suit or showed any other discernible link to the claimed technology. ${ }^{76}$ Furthermore, the other two so-called "straight" licenses arose out of litigation over the patents-in-suit. ${ }^{77}$ The Federal Circuit noted that the rates in the re-bundling licenses were much larger than the rates of the straight licenses, and that one of the straight licenses was a lumpsum payment of stock that the expert could not equate to a running royalty rate. ${ }^{78}$ The other straight license was an ongoing rate averaging substantially less than 12.5 percent of revenues. ${ }^{79}$

Considering the nature of all seven licenses, the Federal Circuit stated that "the most reliable license in this record arose out of litigation," referring to the straight license with an ongoing rate ${ }^{80}$ The court noted that "[o]n other occasions, this court has acknowledged that the hypotherical reasonable royalty calculation occurs before litigation and that litigation itself can skew the results of the hypothetical negotiation." ${ }^{\text {"11 }}$ Furthermore, the court acknowledged that "a reasonable royalty can be different than a given royalty when, for example, widespread infringement artificially depressed past licenses." "82 Prior to this statement, the court also noted that "the record already contained evidence of licenses on the claimed technology."

Upon remand, the court directed that "the trial court should not rely on unrelated licenses to increase the reasonable royalty rate above rates more clearly linked to the economic demand for the claimed technology." ${ }^{184}$ The court concluded by saying that "the district court erred by considering ResQNet's re-bundling licenses to significantly adjust upward the reasonable royalty without any factual findings that accounted for the technological and economic differences between those licenses and the ' 075 patent. ${ }^{\prime 25}$

In a dissenting opinion, Circuit Judge Newman took issue with the majority's emphasis on the license arising out of litigation and the dismissal

76. $I d$.

77. Id.

78. Id. at $870-71$.

79. Id. at 870 .

80. Id. at 872 .

81. Id. (citing Hanson v. Alpine Valley Ski Area, Inc., 718 F.2d 1075, 1078-79 (Fed. Cir. 1983)).

82. Id.

83. Id.

84. Id. at $872-73$.

85. Id. at 873 . 
of the other licenses. ${ }^{86}$ The dissent noted the district court's recognition that settlement of ongoing litigation can involve considerations quite different from the "hypothetical negotiation" conducted on the premise that the patent is valid and would be infringed. ${ }^{87}$ Accordingly, the dissent found it reasonable that the district court approved of a royalty higher than that in the litigation settlement, but much lower than any of the licenses that included the software code. ${ }^{88}$

Acknowledging the majority's emphasis on the settlement license, the dissent noted that " $[t]$ he panel majority thus appears to exclude all evidence except for the royalty in the settlement agreement between ResQNet. and [the licensee]," ${ }^{39}$ and that "[i]n contrast to precedent, the panel majority moves the [settlement] agreement to the forefront of the analysis." dissent also points out that even Lansa argued that the royalties of litigationinduced licenses should not be considered. ${ }^{.1}$

\section{SUbSEQUENT INTERPRETATION BY District COURTS}

Several courts have addressed the ResQNet decision with respect to the admissibility of litigation licenses or the discovery of settlement negotiations. ${ }^{92}$ These courts have reached varying and conflicting interpretations of the opinion. Some hold that ResQNet altered the admissibility of settlement licenses, while others claim that nothing has changed. ${ }^{93}$ The following sections provide a summary of the cases that have considered the ResQNet opinion regarding the admissibility of settlement licenses and discovery of settlement negotiations.

86. Id. at 878 (Newman, J., dissenting) ("The [lump sum, litigation-induced] license is relevant, for the lump sum amount therein is substantially greater than the amount that was here awarded to ResQNet.").

87. Id. at $878-79$.

88. Id.

89. Id.

90. Id. at 880 .

91. Id.

92. See, e.g., Phillip M. Adams \& Assocs., LLC v. Asustek Computer, Inc., No. 1:05CV-64 TS, 2010 WL 3069898, at *2 (D. Utah Aug. 4, 2010); ReedHycalog UK, Ltd. v. Diamond Innovations Inc., No. 6:08-CV-325, 2010 WL 3021550, at *1 (E.D. Tex. Aug. 2, 2010); Software Tree, LLC v. Red Hat, Inc., No. 6:09-CV-097, 2010 WL 2788202, at *1-4 (E.D. Tex. June 24, 2010); Fenner Invs., Ltd. v. Hewlett-Packard Co., No. 6:08-CV-273, 2010 WL 1727916, at *1, *3 (E.D. Tex. Apr. 28, 2010); Datatreasury Corp. v. Wells Fargo \& Co., No. 2:06-CV-72 DF, 2010 WL 903259, at*1-2 (E.D. Tex. Mar. 4, 2010); Tyco Healthcare Group LP, v. E-Z-Em, Inc., No. 2:07-CV-262 (TJW), 2010 WL 774878, at *2 (E.D. Tex. Mar. 2, 2010).

93. See infra Sections II.C.1-II.C.2. 


\section{Eastern District of Texas Courts Disagree Over ResQNet's Applicability}

Several cases in the Eastern District of Texas have already discussed ResQNet. The first case was Tyco Healthcare Group LP v. E-Z-EM, Inc., which held that settlement licenses and related negotiations were discoverable. ${ }^{94}$ In an opinion by Judge Ward, the court acknowledged that " $[t]$ his Court has in the past ... adopted a bright-line rule that settlement negotiations are privileged while the resulting license agreement is discoverable." 95 Directly addressing the ResQNet opinion, the court said, "[ResQNet] causes the Court to shift its approach toward the discoverability of settlement negotiations." Although it recognized that "litigation itself can skew the results of the hypothetical negotiation," the court allowed discovery of the settlement negotiations because "the parties are entitled to show whether and to what extent the rate from a prior license agreement is the result of a compromise or reflects a desire to avoid litigation." ${ }^{.97}$ The court concluded that "in light of the admissibility and importance of prior related settlement agreements, ResQNet suggests that the underlying negotiations are relevant to the calculation of a reasonable royalty using the hypothetical negotiation damages model." $" 98$

Two days later, in Datatreasury Corp. v. Wells Fargo \& Co., the court admitted litigation-related licenses and permitted discovery of the settlement negotiations. ${ }^{99}$ The issue before Judge Folsom was "whether the litigationrelated licenses (including their amounts) [were] admissible for essentially all purposes." 100 The court permitted supplemental briefing on the issue because of ResQNet. ${ }^{101}$ In spite of the contention by defendants that ResQNet did not directly address admissibility and involved a bench trial instead of a jury trial, ${ }^{102}$ the court held that "[i]n light of ResQNet, litigation-related licenses should not be excluded." 103 The court reasoned that "[a]lthough ResQNet involved a bench trial, the licenses at issue were considered by that trial court

94. Tyco, $2010 \mathrm{WL} 774878$, at *2.

95. Id.

96. $I d$.

97. Id.

98. Id.

99. Datatreasury Corp. v. Wells Fargo \& Co., No. 2:06-CV-72 DF, 2010 WL 903259, at

*2 (E.D. Tex. Mar. 4, 2010).

100. Id.

101. Id. at $* 1$.

102. The possibility of unfair prejudice and jury confusion are not a concern in bench trials because there is no jury.

103. Datatreasury, 2010 WL 903259 , at *2. 
sitting as trier of fact, just as the jury will sit in [this] case." 104 To reduce potential jury confusion, the court allowed the parties to propose final jury instructions providing guidance on applying litigation-related licenses. ${ }^{105}$ The court also ruled that the defendants were entitled to discovery of the negotiations surrounding the admitted litigation-related licenses. ${ }^{106}$

The next case from the Eastern District of Texas to address the issue took the opposite approach. In Fenner Investments L.td. v. Hewlett-Packard Co., Magistrate Judge Love refused to admit evidence and testimony relating to settlement agreements in prior litigation. ${ }^{107}$ In response to defendants' assertion that, based on ResQNet, they should be allowed to introduce settlement licenses entered into as a result of prior litigations with third parties, the court stated that the "ResQNet decision has not altered the admissibility of agreements entered into under the threat of litigation." 108 The court noted that "[i]n ResQNet, the litigation-related licenses were part of the record and their admissibility was not before the court." ${ }^{109}$ Additionally, the court emphasized that there was no risk of jury confusion because ResQNet was a bench trial. ${ }^{110}$ The court proposed that the "most reliable license" comment was made in the context of evaluating an expert's application of the first Geongia-Pacific factor to the licenses in the record. ${ }^{11}$ The court also expressed concern that allowing settlement licenses could invite mini-trials on the similarities and differences between the present case and the settled claims, implying that the potential value of a settlement license is not worth the effort required to determine its appropriate weight. ${ }^{12}$

In Software Tree, LLC v. Red Hat, Inc., Judge Love maintained the position taken in Fenner. ${ }^{13}$ At issue was defendant's motion to compel production of plaintiff's settlement negotiations related to licenses for the patent-in-suit. ${ }^{114}$ The licenses were part of settlement agreements by co-defendants in the

104. Id.

105. Id.

106. Id.

107. Fenner Invs., Ltd. v. Hewlett-Packard Co., No. 6:08-CV-273, 2010 WL 1727916, at

*3 (E.D. Tex. Apr. 28, 2010).

108. Id.

109. Id.

110. Id.

111. Id.

112. Id.

113. Software Tree, LIC v. Red Hat, Inc., No. 6:09-CV-097, 2010 WL 2788202, at *4

(E.D. Tex. June 24, 2010).

114. Id. at $* 1$. 
same case. ${ }^{115}$ The plaintiff produced the license agreements but not the underlying negotiations. ${ }^{116}$ The court held that statements made in furtherance of settlement are privileged and protected from third-party discovery because there is "a strong public interest in favor of secrecy of matters discussed by parties during settlement negotiations." suggested that the existence of the talks or the agreement may be admissible, but the content of the talks or agreement are not, and that any communications made in furtherance of settlement are privileged. ${ }^{118}$ Responding to the longstanding bias against admitting settlement licenses, the court said that "[t] he Federal Circuit's decision in ResQNet has called this "bright-line' rule into considerable question," but that it "did not alter the law regarding discoverability." As stated in Software Tree, "[]itigation licenses, and the negotiations underlying them, are not probative of the fair value of a patent, but rather are probative of the value of settling a particular case." ${ }^{120}$ The court noted that the discoverability of negotiations underlying the licenses in ResQNet was not before the court, ${ }^{121}$ but did cite a few cases where discovery was allowed by other courts. ${ }^{122}$ Ultimately the court held that "[c]ontinuing to exclude underlying negotiations is consistent with [the] Court's past decisions ... and is most appropriate given the chilling effect such discovery would have on settlements."123

The Software Tree court also weighed in on when a license is considered to be induced by litigation. Regarding other licenses in question, the court held that the contention that the possibility of litigation was discussed prior to entering an agreement is insufficient to qualify a license for privileged status. "Absent a stronger showing that the licenses were entered into within the context of litigation, ... the [] agreements are not subject to the settlement privilege." 124

Finally, in ReedHycalog UK, Ltd. v. Diamond Innovations, Inc., Judge Davis followed the Fenner and Software Tree line of cases in rejecting the admissibility

115. $I d$.

116. Id.

117. Id.

118. Id. at $* 2$ (noting that Federal Rule of Evidence 408 generally bars admission of settlement agreements).

119. Id.

120. Id. at *4.

121. Id. at *3.

122. Id. at *4.

123. Id.

124. Id. 
of litigation licenses. ${ }^{125}$ The court acknowledged that "based on [ResQNet], some parties are arguing, and some courts are finding, that settlement licenses are admissible to prove a reasonable royalty."126 The defendant moved to prohibit any evidence regarding any previous litigation settlements or discussions. ${ }^{127}$ The court denied the motion, but allowed evidence of settlement licenses provided they would not be identified as litigation licenses. ${ }^{128}$ Again, the court recognized that admissibility was not at issue before the Federal Circuit in ResQNet. ${ }^{129}$ Furthermore, the court stated that the emphasis on the litigation license in ResQNet was "merely a reflection on the evidence before it," and "not the adoption of a bright-line rule regarding the reliability of litigation licenses nor even a ruling on their admissibility." 130 Despite these comments, the court supported the position that settlement licenses are admissible under certain circumstances: "After considering ResQNet and other case law, ... the admissibility of litigation licenses-like all evidence-must be assessed on a case-by-case basis, balancing the potential for unfair prejudice and jury confusion against the potential to be a "reliable license." 131

\section{Treatment by Other District Courts Has Also Varied}

Outside the Eastern District of Texas, Phillip M. Adams \& Associates. LLC v. Asustek Computer, Inc. concerned a consent judgment involving a previous settlement between the plaintiff and another party. ${ }^{132}$ The judgment declared that the plaintiff's patent was valid and that the defendant admitted to infringement. ${ }^{133}$ The plaintiff argued that settlement agreement was admissible as a secondary consideration to show commercial success and nonobviousness. ${ }^{134}$ The defendant sought to exclude the judgment as hearsay, prejudicial, irrelevant, and confusing to the jury. ${ }^{135}$ The court admitted the settlement because the defendant's expert relied heavily on the

125. ReedHycalog UK, Ltd. v. Diamond Innovations Inc., No. 6:08-CV-325, 2010 WL 3021550, at *4 (E.D. Tex. Aug. 2, 2010).

126. Id. at *1.

127. Id.

128. Id. at *4.

129. Id. at $* 2$.

130. Id.

131. Id. at *3.

132. Phillip M. Adams \& Assocs., LLC v. Asustek Computer, Inc., No. 1:05-CV-64 TS, 2010 WL 3069898, at *1 (D. Utah Aug. 4, 2010).

133. Id.

134. Id.

135. Id. at $* 2$. 
licenses to challenge the plaintiff's damages calculation and therefore made the licenses an issue. ${ }^{136}$ The court reasoned that "[i]f such arguments are raised by Defendants at trial, Plaintiff is entitled to explore why the ... settlement and licence [sic] supports its theory of damages."137 Although the court admitted the settlement, it excluded portions of the consent judgment that would be confusing to the jury and prejudicial to the defendants. ${ }^{138}$

In Douglas Dynamics, LLC v. Buyers Products Co., the plaintiff sought to exclude evidence relating to a cross-license agreement involving its own patent that resulted from a settlement that the plaintiff entered into in a different patent infringement case. ${ }^{139}$ Based on ResQNet, the court stated that "[b]ecause determining a reasonable royalty is a fact-specific inquiry dependent on the consideration of many factors, even licenses arising from resolution of unrelated patent litigation can ordinarily be considered."1140 Although the court left open the possibility of admission, the license was ultimately excluded. Since the patent was no longer at issue, the court held that its relevance was "extremely weak" and that "the probative value of th[e] license [was] substantially outweighed by unfair prejudice to plaintiff and by the likely confusion it would create for the jury." ${ }^{\text {"141 }}$

\section{DISCUSSION}

\section{A. AdMISSiBility OF LitigATION-INDUCED LiCENSES SHOULD BE DETERMINED CASE-BY-CASE}

The cases subsequent to ResQNet show the various ways the opinion is affecting how district courts deal with admissibility and discovery relating to settlement licenses. ${ }^{142}$ The cases also demonstrate the wide range of circumstances surrounding settlement licenses. Because settlement licenses may arise under any number of different conditions, courts should determine admission of the agreements and discovery of the underlying negotiations on a case-by-case basis after considering the relevant rules of evidence and civil procedure. This is the position taken by the court in ReedHycalog. ${ }^{143}$ As

136. Id.

137. Id.

138. Id.

139. Douglas Dynamics, LLC v. Buyers Prods. Co., No. 09-CV-261-WMC, 2010 WL 4118098, at *1 (W.D. Wis. Oct. 8, 2010).

140. Id. (internal citations omitted).

141. Id.

142. See supra Section II.C.

143. ReedHycalog UK, Ltd. v. Diamond Innovations Inc., No. 6:08-CV-325, 2010 WL 3021550, at *4 (E.D. Tex. Aug. 2, 2010). 
opposed to bright-line rules, a flexible standard allows courts to account for specific circumstances in any particular case.

Although the court in ResQNet did not specifically address admissibility of settlement licenses, courts have used the opinion's focus on settlement licenses to give such licenses more probative value. Tyco and Datatreasury imply that because settlement licenses were the most reliable in the ResQNet case, they may also be reliable in other cases. ${ }^{144}$ The Federal Circuit also stated that upon remand "the trial court should not rely on unrelated licenses to increase the reasonable royalty rate above rates more clearly linked to the economic demand for the claimed technology." the litigation license is the "most reliable in this record," this statement implies that settlement licenses can have significant probative value. If Tyco and Datatreasury are accurate representations of the law, the significance of settlement licenses has increased from their prior status of being dismissed almost out of hand. These decisions effectively rebut the presumption that settlement licenses are inadmissible due to a lack of probative value. But given the ResQNet court's qualifying statements and the negative opinion in Fenner, it would be an overstatement to say that there is now a presumption that settlement licenses have adequate probative value for admission. ${ }^{146}$

Considering the varying interpretations of ResQNet among lower courts, the law is still unclear about whether licenses arising out of litigation should be admissible. As illustrated by the district court cases after ResQNet, there are arguments both for and against admitting settlement licenses in litigation. ${ }^{147}$

In almost any case, the complexities of litigation mean that the licensing terms arising out of litigation are not representative of a license that would result from a hypothetical negotiation under the assumption that the patent is valid and infringed. ${ }^{148}$ If the rate found in a settlement license is favorable for the plaintiff, the defendant can argue that a previous defendant paid a premium to avoid the costs of further litigation or to evade the risk of a large

144. See Datatreasury Corp. v. Wells Fargo \& Co., No. 2:06-CV-72 DF, 2010 WL 903259 , at *2 (E.D. Tex. Mar. 4, 2010); Tyco Healthcare Group LP, v. E-Z-Em, Inc., No. 2:07-CV-262 (TJW), 2010 WL 774878, at *2 (E.D. Tex. Mar. 2, 2010).

145. ResQNet.com, Inc. v. Lansa, Inc., 594 F.3d 860, 872-73 (Fed. Cir. 2010) (emphasis added).

146. ResQNet, 594 F.3d at 872 . The ResQNet court said that the licenses were the most reliable "in this record," while also warning of the effects of litigation.

147. See supra Section II.C.

148. ResQNet, 594 F.3d at 880 (Newman, J., dissenting) ("The unpredictability of patent litigation remains notorious."). 
verdict. The defendant might also argue that admission of a settlement license creates an unfair presumption that the patent is valid simply because another defendant settled. ${ }^{149}$ If the license is favorable for the defendant, the plaintiff could argue that the rate represents a discount due to the plaintiffs efforts to avoid the costs of further litigation. The patentee could also argue that it accepted a lower rate to eliminate any risk of a finding of invalidity or unenforceability, which could end the current litigation and inhibit future actions against other alleged infringers. ${ }^{150}$ This would be difficult to argue, however, because it shows a lack of confidence by the plaintiff in its own patent. Additionally, the court in ResQNet recognized that widespread infringement can also artificially depress license rates. ${ }^{151}$ Although not unique to litigation licenses, this is another argument the plaintiff could potentially use.

There are also valid reasons for permitting courts to admit settlement licenses. In cases where evidence of a reasonable royalty is severely limited (e.g., there are no licenses for the patent-in-suit that did not arise out of litigation), the probative value of a settlement license involving the patent-insuit might be relatively high, outweighing the potential for unfair prejudice or confusion. This position is consistent with a conservative interpretation of ResQNet-that in a particular case, a license arising out of litigation may have the most relevance. Allowing a settlement license into the record may also be appropriate when denying admission would unfairly prejudice one of the parties, such as the situation in Phillip. ${ }^{152}$ Where one party has already used a settlement license as part of its argument, refusing to allow further use may unfairly prejudice the other party.

Allowing settlement licenses under certain circumstances would also help alleviate the concern of "sham" lawsuits. If settlement licenses were inadmissible under any circumstances, cooperative parties could formally initiate litigation to keep their agreement privileged even when no true controversy exists. This would reduce the amount of relevant evidence in subsequent litigation by protecting agreements that accurately represent a hypothetical negotiation between two willing parties, and should otherwise be disclosed.

149. See supra Section I.B.

150. Fenner Invs., Ltd. v. Hewlett-Packard Co., No. 6:08-CV-273, 2010 WL 1727916, at *3 (E.D. Tex. Apr. 28, 2010).

151. ResQNet, 594 F.3d at 872 (majority opinion).

152. See supra Section II.C.2. 
Deciding admissibility on a case-by-case basis also gives the courts flexibility to apply conditions on admissibility. Some courts have already shown a willingness to allow settlement licenses after ResQNet under specified conditions and limitations. ${ }^{153}$ For example, the court in ReedHycalog decided to allow evidence of settlement licenses under the condition that the licenses would not be defined or identified as litigation licenses. ${ }^{154}$ Also, the Datatreasury court said that jury instructions would be appropriate. ${ }^{155}$ Alternatives such as limiting instructions and redaction allow courts to maintain the probative value of a license while reducing the possibility of confusion or unfair prejudice.

The alternative to deciding admissibility of settlement licenses on a caseby-case basis would be to instate an across-the-board exclusion or admission of all relevant licenses arising out of litigation. Both options would reduce uncertainty in the litigation process. Admitting all related settlement licenses would increase the amount of relevant evidence. Excluding them would increase efficiency and reduce potential for confusion and unfair prejudice. ${ }^{156}$ Even if the influences of litigation in a particular case did not affect the probative value of a license, as a matter of overall policy, the efforts required to determine the value of settlement licenses may not be worth whatever probative value they would provide. ${ }^{157}$

Regardless of the potential benefits of a uniform admission or exclusion rule, neither is likely to be adopted. An across-the-board rule in either case is inconsistent with Federal Rule of Evidence 403, because Rule 403 is a general balancing rule without any topic-specific exceptions. Also, blanket admission would represent a complete reversal of the traditional bar against these types of licenses. ${ }^{158}$ It would also directly conflict with Rule 408 when the

153. See supra Section II.C.

154. ReedHycalog UK, Ltd. v. Diamond Innovations Inc., No. 6:08-CV-325, 2010 WL 3021550, at *4 (E.D. Tex. Aug. 2, 2010).

155. Datatreasury Corp. v. Wells Fargo \& Co., No. 2:06-CV-72 DF, 2010 WL 903259, at *2 (E.D. Tex. Mar. 4, 2010) (allowing both parties to propose jury instructions giving guidance on applying litigation-related licenses).

156. Fromson v. Western Litho Plate \& Supply Co., 853 F.2d 1568, 1574 (Fed. Cir. 1988) ("Determining a fair and reasonable royalty is often ... a difficult judicial chore, seeming often to involve more the talents of a conjurer than those of a judge."); Fenner Invs., Ltd. v. Hewlett-Packard Co., No. 6:08-CV-273, 2010 WL 1727916, at *3 (E.D. Tex. Apr. 28, 2010) (expressing concern that admitting settlement licenses would invite "minitrials").

157. The efficiency argument is similar to the mini-trial concern in Fenner. Fenner, 2010 WL 1727916, at*3.

158. See supra Section I.A. 
negotiated licenses are clearly offers to compromise or offered to prove the validity or amount of a claim. Also, even if prohibiting evidence of all settlement licenses could be reconciled with Rule 403, denying admission based on Rule 408 may be challenging because of the difficulty in determining when a claim is actually disputed. Rule 408 applies not only when there is continuing litigation, but also when there was a threat of litigation or when litigation was probable. ${ }^{159}$ For example, as mentioned in Software Tree, the possibility that litigation was discussed prior to entering into the agreement was not enough to convince the court that a license arose out of litigation. ${ }^{160}$ The uncertainty in Rule 408 would reduce the efficiency benefits of an outright exclusion rule.

\section{B. Ambiguity Remains About How to Use Settlement Licenses IN REASONABLE ROYALTY ANALYSIS}

If settlement licenses are admitted for use in reasonable royalty analysis, ResQNet does not resolve whether they should be treated differently from other licenses. Generally, a reasonable royalty is the royalty that willing parties would have agreed to had they negotiated a license for the patent. ${ }^{161}$ To be applicable, "the rate must be supported by evidence in the record and not mere conjecture," 162 and licenses must be linked to the infringed patent so that the fact finder can "adequately evaluate[] the probative value of [the] agreements." 163

Although the ResQNet court stated that the litigation license was the most reliable in that case, it did not provide general guidance on factoring settlement agreement rates into a reasonable royalty analysis. ${ }^{164}$ The dissent noted that the expert acknowledged that factors involved in litigation can affect the negotiated rate, and proposed a rate between the rate in the settlement license and the significantly higher rates in the re-bundling licenses. ${ }^{165}$ This suggests that the expert believed that the settlement rate represented a discount from the true value of the patent. The majority rejected the relevance of the re-bundling licenses, which were used at least in

159. PharmaStem Therapeutics, Inc. v. Viacell Inc., A.A. 02-148 GMS, 2003 WL 22387038, at *2 (D. Del. Oct. 7, 2003).

160. See Software Tree, LLC v. Red Hat, Inc., No. 6:09-CV-097, 2010 WL 2788202, at *4 (E.D. Tex. June 24, 2010).

161. 7 CHISUM, supra note $11, \$ 20.03$.

162. Id.

163. Lucent Techs., Inc. v. Gateway, 580 F.3d 1301, 1328 (Fed. Cir. 2009).

164. ResQNet.com, Inc. v. Lansa, Inc., 594 F.3d 860, 872 (Fed. Cir. 2010).

165. Id. at $877-78$ (Newman, J, dissenting). 
part by the expert, and vacated the damage award. ${ }^{166}$ Although the ResQNet court did not provide specific guidance on valuing the settlement rate, it implied that the settlement rate, which was "substantially less" than 12.5 percent, did not justify this proposed rate. ${ }^{167}$

In practice, courts rarely establish a lower rate than in prior or existing licenses. ${ }^{168}$ The rate determined by the court may be greater than in prior and existing licenses if the patent owner can demonstrate that prior rates were depressed, either by widespread infringement and defiance of the patent or by pressure to settle threatened or pending litigation. ${ }^{169}$ On the other hand, alleged infringers could also argue that the effects of litigation potentially increased royalty rates in settlement agreements. ${ }^{170}$

Despite the tendency to set the reasonable royalty at a rate greater than the rate in existing or prior licenses, the court in ResQNet held that "the trial court should not rely on unrelated licenses to increase the reasonable royalty rate above rates more clearly linked to the economic demand for the claimed technology."171 If one assumes that "rates more clearly linked to the economic demand for the claimed technology" referred to the rate in the litigation-induced license, then the awarded rate would be capped at the rate in the settlement license. As Judge Newman notes in the dissent, this approach "assur[es] the infringer, after losing in litigation, of no worse penalty than the lowest royalty previously accepted in settlement."172 Furthermore, it would "make an election to infringe a handy means for competitors to impose a 'compulsory license' policy upon every patent owner." ${ }^{\text {"173 }}$ Given the general trend of setting the reasonable royalty at a rate greater than that in prior licenses, limiting the rate to that of a previous or existing license would be a significant change. Also, because of the emphasis on settlement licenses in ResQNet, it is unclear whether such a rule would apply only to litigation-induced licenses or would apply more generally.

Overall, without knowing the specific conditions under which a license arose, it is difficult to forecast whether the rates found in settlement licenses should be discounted or enhanced to account for the effects of litigation.

166. ResQNet, 594 F.3d at 870 (majority opinion).

167. Id. at 871 .

168. 7 CHISUM, supra note $11, \$ 20.03$.

169. Id.

170. See supra Section III.A.

171. ResQNet, 594 F.3d at 872-73.

172. Id. at 880 (Newman, J, dissenting).

173. Id. (quoting TWM Mfg. Co. v. Dura Corp., 789 F.2d 895, 900 (Fed. Cir. 1986)). 


\section{THE EFFECTS OF ADMITTING SETTLEMENT LICENSES AND INCREASING DISCOVERY OF SETTLEMENT NEGOTIATIONS}

The decisions following ResQNet that promote increased discovery of negotiations leading to a settlement license are a direct assault on the promotion and encouragement of open settlement communications. These holdings have received significant attention from practitioners and are causing uncertainty and concern among in-house counsel. ${ }^{174}$ Expanding discovery of settlement negotiations creates concerns beyond those resulting from admitting settlement licenses-specifically that negotiations will be used against parties in subsequent litigation and will make parties more reserved, more calculated, and ultimately less likely to settle claims in the future. ${ }^{175}$

\section{Discovery of Settlement Negotiations Is of Greater Concern Than Admission of the Final Agreement}

Although increased disclosure of settlement negotiations would be a significant change from present expectations, discovery of the agreements themselves would not represent a dramatic change from current litigation practice. The admissibility of settlement agreements may result in more disclosure of licensing terms, but many courts already require parties to disclose prior agreements during litigation, regardless of whether they resulted from litigation or not. ${ }^{176}$ As such, parties have grown accustomed to being forced to disclose the terms of prior agreements. ${ }^{177}$

174. See, e.g., E. Danielle Thompson Williams and Leslie T. Grab, Contemporary Issues in Patent Royalty Damages; TMI: How Much Settlement Information is Too Much Settlement Information?, PRACTICING LAW INSTITUTE (October 13, 2010), http://patentlawcenter.pli.edu/2010/10/ 13/contemporary-issues-in-patent-royalty-damages/; Edward A. Gold, Interpreting LitigationRelated Licenses for Damages, INVOTEX (Fall 2010), http://www.invotex.org/lit_perspectives_ 1010.html\#31010; Robert A. Matthews, Jr., Possible Sbift in the Treatment of License Rates, IPFRONTLINE.COM (March 31, 2010), http://www.ipfrontline.com/depts/article.aspx?id= 24187\&deptid=7; Jayme Partridge, Unwinding a Case: Issues That May Arise Regarding Settlement Agreements in Patent Infringement Litigation (2010) (unpublished), http://works.bepress.com/ jayne_piana/1/.

175. See, e.g., Lake Utopia Paper Ltd., v. Connelly Containers, Inc., 608 F.2d 928, 930 (2d. Cir. 1979) (discussing the importance of confidentiality in resolving disputes: "If participants cannot rely on [confidentiality] then counsel of necessity will feel constrained to conduct themselves in a cautious, tight-lipped, non-committal manner more suitable to poker players in a high-stakes game than to adversaries attempting to arrive at a just resolution of a civil dispute.").

176. See supra Section I.C.3.

177. See, e.g., Goodyear Tire \& Rubber Co. v. Chiles Power Supply, Inc., 332 F.3d 976, 981 (6th Cir. 2003). 
Furthermore, disclosure outside the context of litigation may be common. A licensor may have legitimate motives for disclosing the terms of prior licenses in order to increase trust with potential licensees and promote efficient negotiations. ${ }^{178}$ Prior agreements can provide a useful reference point for all parties involved in a negotiation. Otherwise, each negotiation begins from scratch, which may be an inefficient strategy. Licensees want to know what others have paid for a particular technology, while the licensor can likely reveal "standard pricing" without sacrificing significant negotiating advantage. Depending on the circumstances, it is unlikely that a licensor will safeguard prior agreements to the point that it prevents productive negotiations. This may be especially true when a patentee is seeking to negotiate with a large number of potential licensors where efficiency is of greater concern. Overall, if the benefit of revealing the terms of a prior license exceeds the potential gain of keeping them secret, the licensor will want to reveal the terms. ${ }^{179}$

The value of revealing licensing terms will depend heavily on whether the terms support the licensor's desired outcome and how much the other party values the information. ${ }^{180}$ As such, a licensor may want to keep an agreement secret for a variety of reasons, including unfavorable terms, circumstances that would result in confusion and irrelevant comparisons, competition concerns, or changes in market conditions.

The limited number of cases that go to trial is another reason why the admissibility of settlement agreements is a secondary concern to the discovery of settlement communications. Since few cases go to trial, admission of settlement licenses at trial will not affect the vast majority of patent cases. ${ }^{181}$ The impact of admission at trial would obviously increase to the extent that admission of such licenses chills settlement and causes more trials. However, unless there is a significant increase in trials, over the long run, advantage in settlement negotiations will be more critical than advantage

178. See Ellen E. Deason, The Need for Trust As A Justification for Confidentiality in Mediation: A Cross-Disciplinary Approach, 54 U. KAN. L. REV. 1387, 1403 (2006) (discussing the importance of trust in effective negotiations).

179. Id. at 1401 ("The choices the parties make are based on a cost-benefit analysis comparing the rewards and costs of breaking (or forgoing) trust with maintaining (or creating) it.').

180. 1 Charles B. Craver, Effective Legal Negotiation - and Settlement $\iint 4.01,6.02$ (2001) (discussing the ideas that "knowledge constitutes power in the bargaining context" and that "[n]egotiators should not readily volunteer their most significant information").

181. MENELL ET AL., supra note $1, \$ 2.6$. 
at trial. Since many more cases involve at least some amount of discovery, ${ }^{182}$ allowing discovery of settlement negotiations creates significant potential for parties to obtain a competitor's prior negotiation strategies.

\section{Discovery of Settlement Negotiations Discourages Settlement While Providing Limited Information}

Some courts are relying on ResQNet to expand discovery of negotiations underlying settlements under the assumption that the settlement communications can help evaluate the ultimate agreement. ${ }^{183}$ But the justification of using negotiations to shed light on the relevance and probative value of settlement licenses is misguided. The rationale for using settlement negotiations is that by analyzing communications that occurred in the course of settlement negotiations, one can gain valuable insight into the motives of the parties and their driving considerations. Given this information, one can separate the litigation-related considerations of the parties from statements that reveal the true economic value of the technology.

This justification may make sense theoretically, but it is unlikely to be true in practice. The words spoken during a negotiation are not necessarily true representations of a party's position. ${ }^{184}$ The nature of negotiations, and indeed often the key to negotiating to one's own advantage, is to reveal only that which enhances one's position. ${ }^{185}$ Thus, negotiations can be filled with significant posturing and half-truths that convey little useful information as the parties seek to feel out the other side, establish trust, and gain some advantage. ${ }^{186}$ This is true even if total confidentiality among the parties is assured.

Although the nature of negotiation makes the value of settlement negotiations questionable, prior settlement communications may have some significance if parties assume that their negotiations are not discoverable. ${ }^{187}$ If parties are confident that their negotiations will not be revealed, it is more

182. Id. $\ 1.2$ (noting that approximately 70 percent of patent cases resolve only after at least some court action).

183. See Tyco, Datatreasury, and Phillip discussed supra Sections II.C.1-II.C.2.

184. 1 CRAVER, supra note $180, \$ 1.03$ (discussing the "deliberate deception associated with most legal negotiations").

185. See id. $\$ 54.01,6.02$.

186. See id. $\$ 1.03$.

187. Dunlop v. Bd. Of Governors, 16 F.E.P. Cases 1116, 1117 (N.D. Ill. 1975) (noting that enforcing a privilege for settlement negotiations allows opposing counsel to "feel free to candidly and fully set forth their proposed compromises"). 
likely that they will decide to let down their guard and divulge information or make concessions. ${ }^{188}$ The belief that discussions are confidential can motivate parties to reduce excessive posturing and reveal true strengths and weaknesses to reach a resolution. ${ }^{189}$

Looking forward, however, an environment where negotiations are open to discovery is likely to reduce the already questionable value of these communications. Opening settlement negotiations to discovery or admission will simply exasperate the posturing and tactical nature of the communications. Once parties understand that what they say during settlement negotiations can be used against them in subsequent litigation, different considerations come into play. Parties' focus will shift from resolving the dispute at hand to preventing future litigation risk. Rather than negotiate transparently, parties will seek to convey information that is a careful and calculated balance between their interests in the current litigation and exposure to risk in future disputes.

If a party is unafraid of future repercussions, or believes that dispute over the technology is unlikely to arise again, the confidentiality of negotiations might be of little concern because there is no future risk in revealing information. ${ }^{190}$ In this case, communications may proceed with a focus on maximizing strategic interests in the current controversy. Conversely, a party that foresees continued litigation involving the patent will be reserved about divulging information that may prove harmful in subsequent disputes. However, because parties are likely unable to accurately predict the extent and nature of future liability, it becomes nearly impossible for them to make any type of meaningful tradeoff. ${ }^{191}$ Under these conditions, the parties' uncertainty is more likely to paralyze communication than to encourage the type of open negotiations that facilitates dispute resolution. It is difficult to see any situation where increased discovery of negotiations does not erode the value of these communications in extracting information regarding the

188. Id.

189. Wayne D. Brazil, Protecting the Confidentiality of Settlement Negotiations, 39 HASTINGS L.J. 955, 990 (1988) ("[I]f the law wants to encourage settlement by encouraging frank negotiations, it is important to create an environment in which counsel and parties can be fairly confident that what they say as they negotiate, and the terms of any agreements they might reach, will not be used against them later.").

190. Deason, supra note 178, at 1396 ("If risk for a decision maker is a "perceived probability of loss,' then there is no risk in a decision to take an action unless that action may lead to a loss.").

191. Id. 
merits or value of the claim and in determining their relevance to the current dispute.

As time progresses, the probative value of settlement communications may dissolve further as parties transition from simple future risk avoidance to developing strategies and calculated distortions that may benefit them in subsequent litigation. If courts begin to routinely analyze settlement negotiations in patent disputes, parties will likely seek to use settlement communications offensively to position themselves in subsequent litigation. Parties' ulterior motives will detract attention from resolving the matter at hand and undermine the effectiveness of current negotiations in favor of disputes that may never arise. Over time, the net result is negative for efficient dispute resolution. If parties increasingly negotiate with an eye to future litigation, the resulting settlement communications will provide less value in both the current negotiations and future disputes.

\section{Increased Discovery of Settlement Negotiations Conflicts with Recent Policy Trends}

The decisions in Tyco and Datatreasury are at odds with the modern trend of promoting mediation and settlement through confidential communications. ${ }^{192}$ Due to the costly and time consuming nature of patent litigation, courts should create rules that maximize communication and compromise. ${ }^{193}$ Over the past several decades, federal courts have initiated several efforts aimed at promoting settlement, including encouraging mediation and ensuring confidentiality of discussions. ${ }^{194}$ Many courts now require counsel to discuss how they will attempt to mediate the case, ${ }^{195}$ and

192. Michael P. Dickey, ADR Gone Wild: Is It Time for a Federal Mediation Exclusionary Rule?, 25 OHIO ST. J. ON DISP. RESOL. 713, 714 (2010) ("Beginning with amendments to Rule 16 of the Federal Rules of Civil Procedure (FRCP) in 1983, continuing with the Civil Justice Reform Act of 1990, and culminating in the mandates of the ADR Act of 1998, federal courts integrated alternative dispute resolution generally, and mediation in particular, as a docket management tool.").

193. MENELL ET AL., supra note $1, \$ 2.5$.

194. Dickey, supra note 192, at 714-15 (noting that "[C]ourts and commentators increasingly perceive the mediation process as a means of managing congested dockets," and that "federal courts have ... adopted and enforced rules ostensibly meant to protect the confidentiality of mediation, and gone so far as to sanction parties for bringing motions that described what transpired or what was said at a mediation.").

195. MENELL ET AL., supra note 1, \$2.6.1. "Discussion about mediation may be required by either local rules or standardized order."); see also Dickey, supra note 192, at 715 n.4 ("In response to the ADR provisions of the [Civil Justice Reform Act of 1990], most district courts had implemented mediation programs by 1996."). 
have authority to order participation. ${ }^{196}$ For example, the patent local rules in the Northern District of California have a broad prohibition on disclosure or use outside of mediation of anything said or done in mediation, in order to promote communications. ${ }^{197}$ Rules such as these are based on the strong belief that confidentiality encourages the parties to communicate truthfully, which facilitates settlement.

One possible result of increased discovery is that parties may seek confidentiality safe-havens or arrangements with a strong presumption that any communication between parties will be protected. Given the importance some courts place on protecting settlement communications, courts should respect such confidentiality agreements. ${ }^{198}$ But efforts by federal courts to promote settlement and protect confidential communications have been uncoordinated, resulting in inconsistent or even contradictory approachesthe privilege "appears robust in one jurisdiction but effaces into nonexistence in the next." ${ }^{199}$ Even so, the trend is towards acknowledging a privilege. ${ }^{200}$ Parties negotiating within the confines of these safe havens should have some assurance that courts will uphold the long-standing presumption that such communications are confidential.

\section{CONCLUSION}

In ResQNet the Federal Circuit stated that "the most reliable license in th[e] record arose out of litigation." ${ }^{, 201}$ In response, some district courts have expanded admissibility of settlement licenses and have opened up discovery of the underlying settlement negotiations. ${ }^{202}$ Other courts claim that ResQNet has not changed the admissibility of licenses arising out of litigation. ${ }^{203}$ The varying responses have created uncertainty about whether settlement licenses are admissible in subsequent litigation and how they should be evaluated if admitted. The more troubling trend, however, is the increased discovery of

196. 28 U.S.C. $\iint 651$ (b), 652(a) (2006) (authorizing use of alternative dispute resolution processes in civil actions).

197. MENELl ET AL., supra note $1, \$ 2.6 .5$ (citing N.D. Cal. Patent Local Rule 6-11); see also E.D. Mo. Loc. R. 16-604(A) (ensuring mediation confidentiality).

198. MENELL ET AL., supra note $1, \$ 2.6 .5$.

199. Dickey, supra note 192 , at 731 .

200. Id.

201. ResQNet.com, Inc. v. Lansa, Inc., 594 F.3d 860, 872 (Fed. Cir. 2010).

202. See, e.g., Tyco Healthcare Group LP, v. E-Z-Em, Inc., No. 2:07-CV-262 (TJW), 2010 WL 774878, at *2 (E.D. Tex. Mar. 2, 2010); Datatreasury Corp. v. Wells Fargo \& Co., No. 2:06-CV-72 DF, 2010 WL 903259, at *2 (E.D. Tex. Mar. 4, 2010).

203. See, e.g., Fenner Invs., Ltd. v. Hewlett-Packard Co., No. 6:08-CV-273, 2010 WL 1727916, at*3 (E.D. Tex. Apr. 28, 2010). 
settlement negotiations. Reduced protection of settlement negotiations may have a chilling effect on settlement as parties become fearful of their communications being used against them in future cases. Increased discovery of settlement negotiations also conflicts with courts' recent efforts to promote settlement. Furthermore, the argument that settlement negotiations can assist in evaluating the value of the final agreement is based on a flawed assumption that settlement communications are reliable. Over time, reduced confidentiality of settlement negotiations would likely degrade the effectiveness of settlement efforts, which would have a chilling effect on good-faith settlements and further reduce the usefulness of these communications for evaluating the value of disputed patents. 
